\title{
Використання денситометричного аналізу в практиці торакального хірурга
}

\section{Маєтний Є.М.}

ДУ «Національний інститут фтизіатрії і пульмонології ім. Ф.Г. Яновського НАМН України», м. Київ, Україна

Бажання зазирнути у Всесвіт і в глибини Людини протягом віків надихає вчених. Практичні хірурги здавна вивчають структуру та співвідношення внутрішніх органів й утворень. Важливість отриманих даних важко переоцінити. Яскравим прикладом $€$ праці видатного вченого, хірурга зі світовим ім'ям, засновника топографічної анатомії Миколи Івановича Пирогова. Вільгельм Конрад Рентген у 1895 р. відкрив короткохвильове електромагнітне випромінювання, відоме як рентгенівські промені. Також існують праці Івана Павловича Пулюя, австро-угорського фізика з Галичини, який вивчав електричні розряди у вакуумних трубках за 10 років до відкриття Рентгена, але подальшим розвитком і патентуванням не займався.

Вивчення «рентгенівських тіней» і розвиток обчислювальних технологій зумовили виникнення методу пошарового вивчення внутрішньої будови, запропонованого в 1972 р. Годфрі Хаунсфільдом. Системою реєструються ослаблення опромінення на детекторі та формуються зображення. Візуальна та кількісна оцінка проводиться за шкалою ослаблення рентгенівського опромінення (шкалою Хаунсфільда). Умовно вона розподілена на середину - щільність води, або 0 одиниць Хаунсфільда (HU), та крайні точки: повітря - $1000 \mathrm{HU}$ та кісткова тканина +1000 HU.

Із розвитком томографічного обладнання до «покрокових» апаратів додали детектори, «кроки» перейшли в «спіраль», значно збільшилися кількість детекторів і час обчислення результатів. На сьогодні КТ-реконструкції дають змогу доопераційно виконати віртуальну фібробронхоскопію, вивчити розгалуження артеріальних стовбурів та особливості венозних судин у зоні оперативного втручання. Доопераційне визначення анатомічних особливостей та індивідуальної структури паренхіми допомагає значно оптимізувати оперативне лікування, що особливо важливо при мініінвазивних торакоскопічних втручаннях.

Вивчення особливостей денситометричних змін на тлі лікування дало можливість обґрунтовано встановлювати оптимальні терміни оперативного втручання та прогнозувати наслідки. Передопераційне визначення структури легеневої паренхіми дало змогу підібрати оптимальні заходи запобігання легенево-плевральним ускладненням як інтраопераційно, так і в післяопераційному періоді.

Роботи з визначення структури легеневої паренхіми на основі денситометричних змін допомагають автоматизувати скринінг і первинну діагностику легеневих хвороб. Розроблені за договором співпраці з Національним авіаційним університетом автоматизовані системи дають змогу визначати активність специфічного процесу та відсоток ураження легені. Створено програму виявлення COVIDураження легеневої паренхіми. Завдяки структурнопараметричному синтезу загорткової нейронної мережі можна проаналізувати гістограми легень, отримуючи значно більше інформації від проведеного КТ-дослідження.

У практичній діяльності широко розповсюдженим $\epsilon$ аналіз КT-зображень за допомогою DICOM-VIEWER, як безкоштовних програм, так і професійних. Принциповим за сенситометричного аналізу легеневої паренхіми $\epsilon$ прецизійне виділення на КТ-зрізах ділянок ураження, без залучення просвіту бронха чи каверни. Потрапляння в зону вимірювання повітроносної структури радикально викривляє результати вимірів, роблячи їх нерепрезентативними. Збільшення кількості замірів денситометричних показників у разі збільшення площі досліджуваної ділянки ураженої легеневої паренхіми на якість отриманого результату не вплинуло.

На сьогодні досвід роботи відділу з хворими на COVID-пневмонію продемонстрував можливість контролю перебігу захворювання з огляду на денситометричні зміни. Денситометричний аналіз томограм у разі синдрому плеврального випоту дає змогу доопераційно достовірно визначити транссудат, ексудативні процеси, ускладнення травм органів грудної клітки та згорнутий гемоторакс.

Складно переоцінити вплив денситометричного аналізу КТ органів грудної клітки на тактику лікування фтизіатричних пацієнтів. Встановлено значення щільності для різних фаз специфічного запального процесу, що дає можливість об'єктивно визначати показання до оперативного лікування. 